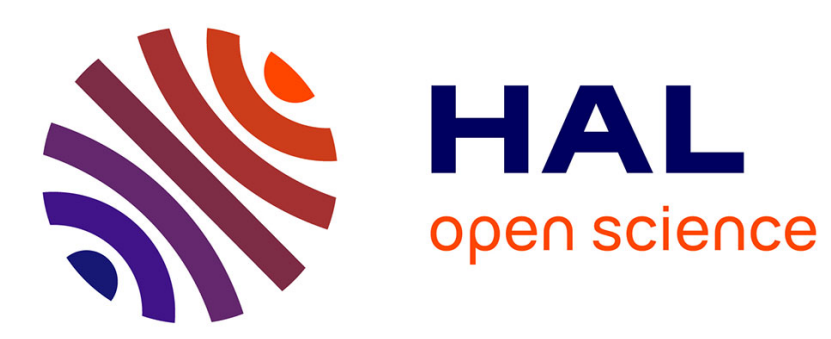

\title{
Characterization and differentiation of human first trimester placenta trophoblastic cells in culture
}

\author{
M Dodeur, A Malassine, D Bellet, A Mensier, D Evain-Brion
}

\section{To cite this version:}

M Dodeur, A Malassine, D Bellet, A Mensier, D Evain-Brion. Characterization and differentiation of human first trimester placenta trophoblastic cells in culture. Reproduction Nutrition Development, 1990, 30 (2), pp.183-192. hal-00899248

\section{HAL Id: hal-00899248 \\ https://hal.science/hal-00899248}

Submitted on 1 Jan 1990

HAL is a multi-disciplinary open access archive for the deposit and dissemination of scientific research documents, whether they are published or not. The documents may come from teaching and research institutions in France or abroad, or from public or private research centers.
L'archive ouverte pluridisciplinaire HAL, est destinée au dépôt et à la diffusion de documents scientifiques de niveau recherche, publiés ou non, émanant des établissements d'enseignement et de recherche français ou étrangers, des laboratoires publics ou privés. 


\title{
Characterization and differentiation of human first trimester placenta trophoblastic cells in culture
}

\author{
M Dodeur ${ }^{*}$, A Malassine 2, D Bellet 3, A Mensier 1, \\ D Evain-Brion 1
}

\author{
'ENS, Laboratoire de Physiopathologie du Développement, CNRS, niveau 8, 46 rue d'Ulm, \\ 75005 Paris; \\ 2 UER des Sciences, 86022 Poitiers; \\ ${ }^{3}$ Institut Gustave Roussy, Département de Biologie Clinique, 94805 Villejuif, France
}

(Received 14 August 1989; accepted 20 December 1989)

\begin{abstract}
Summary - A preparation of highly enriched isolated cytotrophoblasts was obtained from first trimester placenta using dispase incubation of villous tissue at $4{ }^{\circ} \mathrm{C}$, followed by a spontaneous cell release at $37^{\circ} \mathrm{C}$. After $24 \mathrm{~h}$ of culture, $90-95 \%$ of the cells were immunostained by anticytokeratin antibody, showing their epithelial characteristic. After $48 \mathrm{~h}$ of culture, these cells differentiated into syncytiotrophoblast, as shown by optic and electron microscopic study. The secretion of hCG, and of its free $\alpha$ and $\beta$ subunits, and the secretion of hPL were studied as a function of cell culture time. While the level of secreted hCG and its free subunits was stable during $72 \mathrm{~h}$ of culture, the hPL level was undetectable during the first $48 \mathrm{~h}$ of culture, increasing continuously afterwards. Addition of dibutyryl cAMP from the start or after $96 \mathrm{~h}$ of cell culture induced an increase of hCG production and of its free subunits and also stimulated the secretion of hPL. This suggests that these cells maintained the capacity to respond to stimuli which increased intracellular cAMP level. Such a cell culture is of interest in further determining the mechanisms of early gestation involved in the differentiation and growth of placental cytotrophoblasts, and in the regulation of their endocrine functions.
\end{abstract}

\section{cytotrophoblast / syncytiotrophoblast / placental secretion in vitro / human early placenta}

Résumé - Caractérisation et différenciation in vitro de cellules trophoblastiques du placenta humain du premier trimestre. Une préparation hautement enrichie de cellules cytotrophoblastiques est obtenue à partir des villosités choriales du placenta humain du $7^{\text {er }}$ trimestre par incubation à la dispase à $4{ }^{\circ} \mathrm{C}$ suivie d'une dispersion spontanée des cellules à $37^{\circ} \mathrm{C}$. Après $24 \mathrm{~h}$ de culture, 90 à $95 \%$ des cellules sont marquées par un anticorps anticytokératine révélant leur caractéristique épithéliale. Après $48 \mathrm{~h}$ de culture, ces cellules se différencient en syncytiotrophoblastes comme le montrent les études en microscopie optique et électronique. La sécrétion de gonadotrophine chorionique (hCG) et de ses sous-unités libres $\alpha$ et $\beta$ ainsi que la sécrétion d'hormone lactogène placentaire (hPL) ont été étudiées en fonction du temps de culture. Tandis que la sécrétion d'hCG et de ses sous-unités est stable durant les 3 premiers jours de culture, la sécrétion d'hPL est indétectable pendant les premières $48 \mathrm{~h}$ et augmente ensuite progressivement.

L'addition de dibutryl cAMP en continu ou aprés $96 \mathrm{~h}$ de culture induit une augmentation de la sécrétion d'hCG et de ses sous-unités libres $\alpha$ et $\beta$ et stimule aussi la sécrétion d'hPL. Un tel modèle de culture cellulaire sera utile pour étudier les mécanismes impliqués dans la croissance et la diffé-

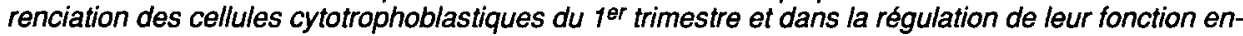
docrine.

cytotrophoblaste / syncytiotrophoblaste / sécrétion placentalre in vitro / placenta humain précoce

* Correspondence and reprints 


\section{INTRODUCTION}

The placenta performs many important functions during pregnancy. It plays an active role in the transport of nutrients and immunoglobulins from the maternal to the fetal circulation and prevents the rejection of the fetus by the mother (Wild, 1983). Moreover, the placenta is an endocrine organ, secreting steroid and protein hormones (Simpson and Mac Donald, 1981). The regulation of these different activities is poorly understood, and most in vitro studies have principally been performed on term placenta. However, first trimester placenta has invasive (Glass et al, 1983), immunological (Chaouat, 1987) and specific endocrine (Lachlan and Lopata, 1988) functions, suggesting that a better understanding of placental biology would be gained by studying the mechanisms necessary for its growth and differentiation, and its hormonal synthesizing capacities in early pregnancy.

Over the past years, many attempts have been made to isolate, purify and maintain human trophoblast cells in culture (Loke, 1983; Zeitler et al, 1983, MacQueen et al, 1987). Recently, Kliman et al (1986) reported a new procedure for trophoblastic cell purification based upon percoll gradient separation after treatment of human term placenta villous tissue by sequential Trypsin and DNase incubations.

Since first trimester placenta villous tissue has different properties and is less fibrous, such trypsin treatment produces some deleterious effects on cytotrophoblast viability and recovery, and increases mesenchymal cell contamination. We report a new method to obtain highly enriched cytotrophoblast preparations using Dispase incubation at $4{ }^{\circ} \mathrm{C}$, followed by a spontaneous cell release at $37^{\circ} \mathrm{C}$ overnight. The isolated cell was characterized by using optic microscopy, electron microscopy, and by studying cell capacity to secrete placental hormones, human chorionic gonadotropin (hCG) and human placental lactogen (hPL) during $7 \mathrm{~d}$ of culture.

\section{MATERIALS AND METHODS}

First trimester placentas were obtained from patients undergoing voluntary elective abortion at 6-12 weeks of amenorrhea. Placental villous tissues were dissected free of chorionic membranes and incubated at $4{ }^{\circ} \mathrm{C}$ for $1 \mathrm{~h}$ in phosphate buffer containing $100 \mu \mathrm{g} / \mathrm{ml}$ of gentamycin and $2.5 \mu \mathrm{g} / \mathrm{ml}$ of amphotericin.

\section{Cell isolation and culture}

The villous tissue was then decanted and incubated with a solution of dispase $(1 \mathrm{ml} / \mathrm{gram}$ of villous tissue at $2.4 \mathrm{U} / \mathrm{ml}$, a neutral protease from Bacillus polymixa (dispase II, EC 3-4-24-4-) in Puck' solution (Boehringer) for $3 \mathrm{~h}$ at $4{ }^{\circ} \mathrm{C}$. The dispase solution was then discarded and the tissue incubated overnight in medium $A$ : DMEM containing $25 \mathrm{mM}$ glucose, $4 \mathrm{mM}$ glutamine, $25 \mathrm{mM}$ HEPES, $100 \mu \mathrm{g} / \mathrm{ml}$ gentamycin, $2.5 \mu \mathrm{g} / \mathrm{ml}$ amphotericin (Seromed Biochrom, Lyon, France) and $20 \%$ of heat-inactivated fetal calf serum (Biological Industries) in $5 \% \mathrm{CO}_{2}$ $95 \%$ air at $37^{\circ} \mathrm{C}$.

During this step, cells were spontaneously released into the medium either as single cells, or aggregated cells. Cells were separated from intact villous core by filtering through a sterile nylon gauze (150 N nylon mesh). In order to increase cell recovery, intact villous tissue on the gauze was washed by medium A $(3 \times 25 \mathrm{ml})$. Cells were collected by centrifugation at $1000 x$ $\mathrm{g}$ for $10 \mathrm{~min}$ and resuspended in medium A (2.5 $\times 10^{5}$ cells/ml). Cell viability, estimated by trypan blue exclusion, was $80 \pm 10 \%$. Cell recovery was routinely $1 \times 10^{6} \mathrm{cells} /$ wet gram of placental villous tissue.

Cells were plated either at $2.5 \times 10^{5}$ cells $/ \mathrm{ml}$ into $35-\mathrm{mm}$ plates coated with human fibronectin (1 $\mathrm{mg} / \mathrm{ml}$, Sigma) for hormonal secretion 
studies, or at $0.5 \times 10^{5}$ cells $/ \mathrm{ml}$ into $1.5 \mathrm{~mm}$ wells coated with human fibronectin for immunohistochemical studies. After $2 \mathrm{~h}$, the medium was removed and replaced with new medium $A$; this step eliminates non-adherent cells and red blood cells. Efficiency of cell plating was routinely $65 \%$.

\section{Immunohistochemical staining of cultured isolated cells}

Immunohistochemical studies were performed at $\mathbf{2 4} \mathrm{h}$ of cell culture. Cells were fixed directly in the wells by formaldehyde $3.7 \%$ (vol/vol-Merck) for $15 \mathrm{~m}$ at room temperature. We used monoclonal antibodies against cytokeratin, undiluted (Pan-cytokeratin, Amersham, France and antivimentin, undiluted (Amersham).

Peroxydase/anti-peroxydase detection was performed according to the manufacturer's instructions (Amersham, France).

\section{Electron microscopy of cultured isolated cells}

After $96 \mathrm{~h}$ of culture, the cells were fixed directly in the plates at $4^{\circ} \mathrm{C}$ for $30 \mathrm{~m}$ with $2.5 \%$ of glutaraldehyde (Sigma) in $0.1 \mathrm{M}$ cacodylate buffer $\mathrm{pH}$ 7.4 , and postfixed with $1 \%$ osmium-tetroxide for 30 min at $4{ }^{\circ} \mathrm{C}$. After ethanol dehydration, the cells were embedded in araldite. For ultrathin cross-section, in situ embedded material was cut into small pieces and re-embedded in araldite. Ultrathin sections were stained with uranyl acetate and lead citrate.

\section{Secretion of $h C G$ and $h P L$ by cultured isolated cells}

Cells were cultured for $7 \mathrm{~d}$ in medium A with epidermal growth factor added $(100 \mathrm{ng} / \mathrm{ml}$, Collaborative Research). Dibutyryl cAMP (mM) was added either immediately, or after $4 \mathrm{~d}$ of culture. The medium was changed daily and stored at $80^{\circ} \mathrm{C}$ until analyzed.

\section{Analytical methods}

Mab-based specific immuno-radiometric assays (IRMAs) were used for the determination of hCG and of free $\alpha$ and $\beta$ subunits of hCG levels in cell culture media. The production of Mabs with defined epitope specificity, the development of multisite IRMAs and the testing of their speciticity have been described previously (Bellet et al, 1986; Ozturk et al, 1987). The level of hPL secreted in the culture medium was determined by hPL IRMA kit (Amersham).

\section{RESULTS}

After $24 \mathrm{~h}$ of culture, the cells formed islands, but individual cells were still discernable. At 48 hours of culture, the cells were all aggregated and individual islands were linked by cell chains (fig 1A). At 72-96 h of culture, multinucleated cells were formed and the syncytium appeared (fig 1B).

At this time, as studied by electron microscopy, the cell surface of the outer part of the clump exhibited cytoplasmic folds, well developed microvilli, and coated and non-coated vesicles. The surface of cells, at the apposition with culture plates, lacked microvilli. Adjacent surfaces of aggregated cells developed desmosomal connections. Internalyzed desmosomes were visible in multinucleated cells. Around the nucleus, the usual cytoplasmic organelles, including a well developed rough endoplasmic reticulum and lysosomes were observed. Osmiophilic lipids, electron-dense vesicles, and numerous cytoplasmic filaments were also present (figs $2 \mathrm{~A}$ and $2 \mathrm{~B}$ ).

After $24 \mathrm{~h}$ of culture, $90-95 \%$ of cells were immunostained by antibody against cytokeratin, demonstrating the epithelial characteristic of cultured cells (fig $3 A$ ), and less than $10 \%$ of cells were positively stained by anti-vimentin antibody, showing a low contamination by mesenchymal and 


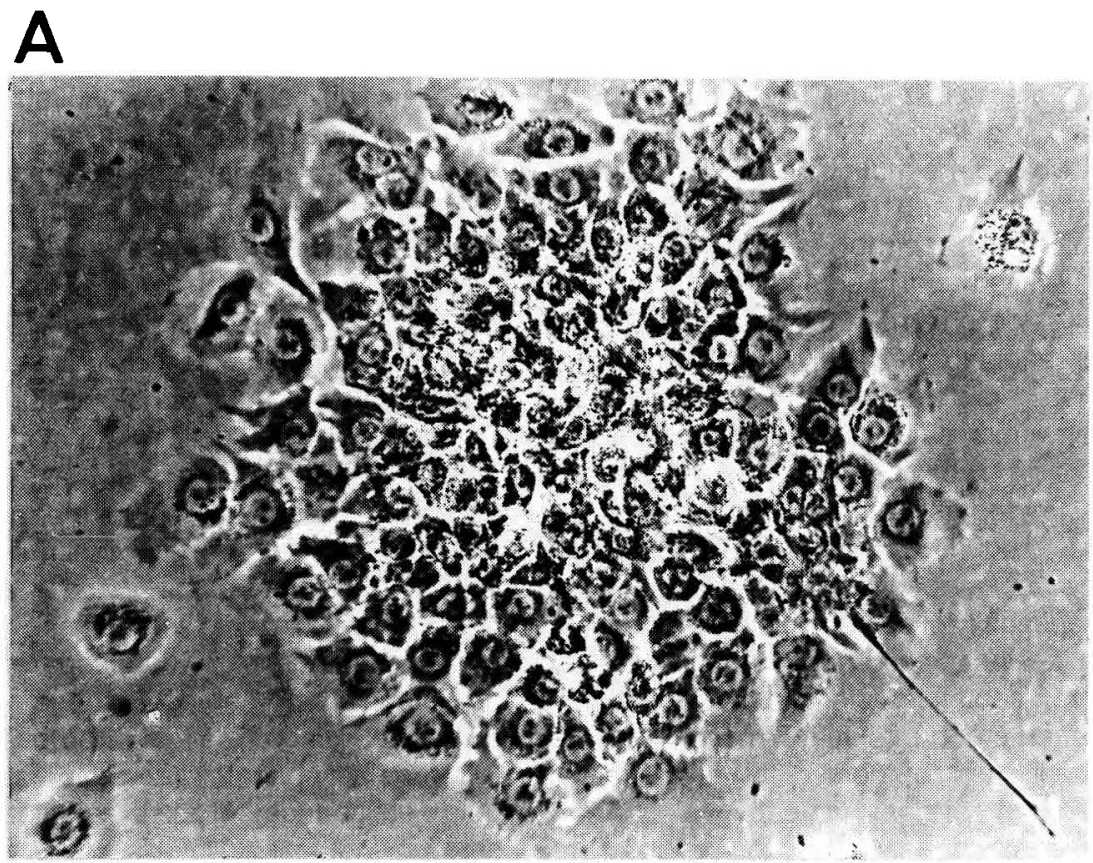

B

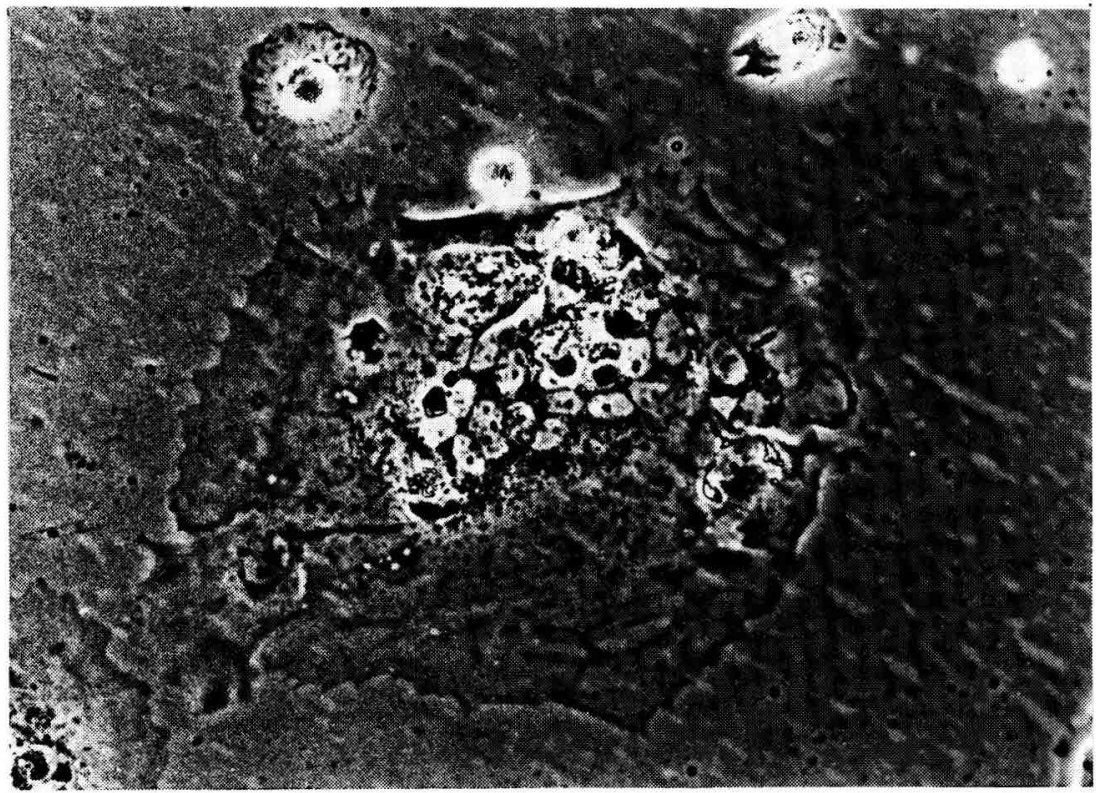

Fig 1. Morphological aspect of trophoblastic cells as a function of culture time $(\times 200)$. A: Cells after $48 \mathrm{~h}$ in culture. B: After $96 \mathrm{~h}$ in culture. 
endothelial cells (fig 3B). This characteristic was maintained at each time of culture.

These immunohistocytochemical and electromicroscopic data showed that the isolated cells from placenta villous tissue, after dispase treatment, were essentially a cytotrophoblast cell type. These cells were able to differentiate in culture by aggregating and fusing to form syncytiotrophoblasts.

\section{HORMONAL SECRETION BY TROPHOBLASTIC CELLS IN CULTURE}

Figure 4 shows the daily secretion of intact hCG (fig 4A), of the free a (fig 4B) and $\beta$ (fig $4 \mathrm{C}$ ) subunits of hCG, and the daily secretion of hPL (fig 4D) by cells cultured for $7 \mathrm{~d}$ in the absence, or in the continuous presence, of dibutyryl cAMP (mM). In the absence of dibutyryl cAMP, the level of secreted intact hCG, and its free $\alpha$ subunit, decreased between the third and fourth $d$ of cell culture and was stable afterwards; the level of free $\beta$ hCG was low at all times of cell culture. The decrease of secreted hCG was not related to a variation in cell viability, as estimated by cell counting, but probably related to the lack of specific synthesis inductors during cell culture. Indeed, the addition of dibutyryl cAMP to the culture medium at the fourth day, induced another increase of secreted intact hCG and its free $\alpha$ and $\beta$ subunits, as soon as the first following $24 \mathrm{~h}$.

When dibutyryl cAMP was present from the start of the culture, the level of intact secreted hCG was maximum on the fourth day $(220 \mathrm{ng} / \mathrm{ml})$, and increased 10 -fold, as compared to the control; the level of secreted free $\alpha$ subunit also reached a maximum at the fourth day $(120 \mathrm{ng} / \mathrm{ml})$, and was increased by 6 -fold, compared to the control; the level of secreted free $\beta$ subunit was stable during the $7 \mathrm{~d}$ of culture $(15 \mathrm{ng} /$ $\mathrm{ml}$, and was increased by 6-fold, compared to the control (d 5 of culture).

The secretion of hPL (fig 4D) was detectable after only $2 \mathrm{~d}$ of culture and increased linearly afterwards. Since hPL secretion was linked with the appearance of multinucleated cells (syncytiotrophoblast), this result supports the idea that cultured cells are able to differentiate in vitro from cytotrophoblasts to syncytiotrophoblasts. In our experimental conditions, the secretion of $\mathrm{hPL}$ was stimulated by the addition of dibutyryl cAMP.

\section{DISCUSSION}

The aim of this work was to obtain a highly enriched cytotrophoblast preparation from first trimester human placental villous tissue. The production of such a cell preparation and the maintenance of these cells in culture should allow further investigation of the mechanisms (hormonal and/or the role of growth factors) involved in the differentiation of the cytotrophoblast into syncytiotrophoblast in the early development of human placenta. Indeed, hormonal secretion, such as hCG (Lachan and Lopata, 1988; Patillo et al, 1983), and the presence of growth and oncogenic factors (Adamson, 1987; Rydnert et al, 1987) associated with the developmental regulation of placenta, were expressed by high levels during the first trimester of gestation and either decreased, or disappeared afterwards.

We report here a method of obtaining highly enriched cytotrophoblast preparations from first trimester placental villous tissue. The cell preparations were not contaminated to any significant extent with endothelial or mesenchymal cells, as demonstrated by the high level of cell immunostaining with anti-cytokeratin antibody 


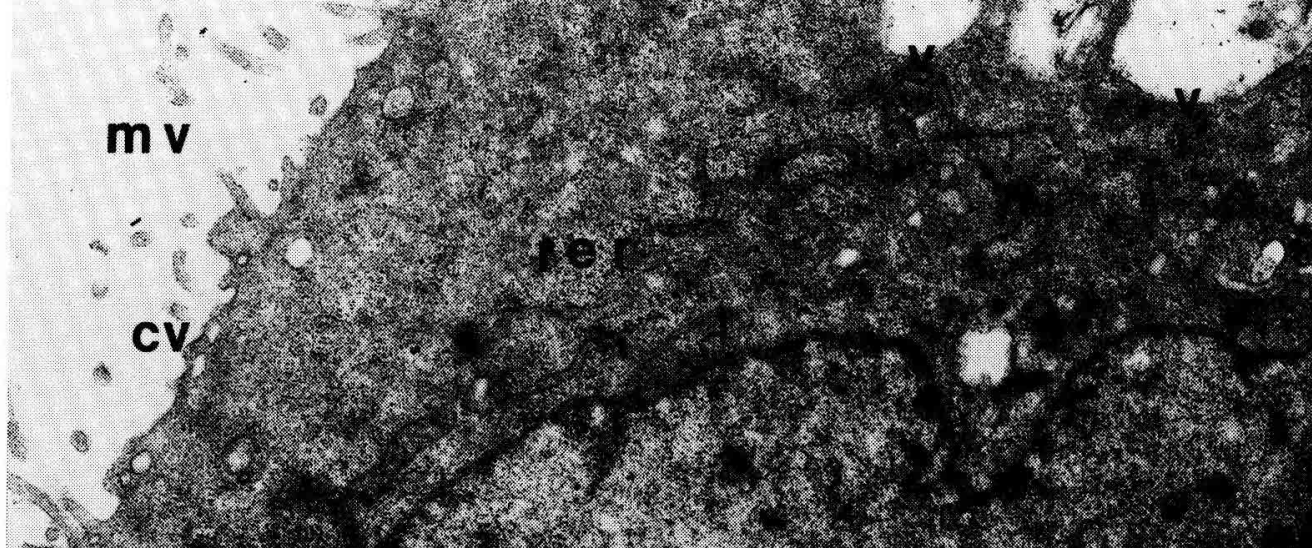

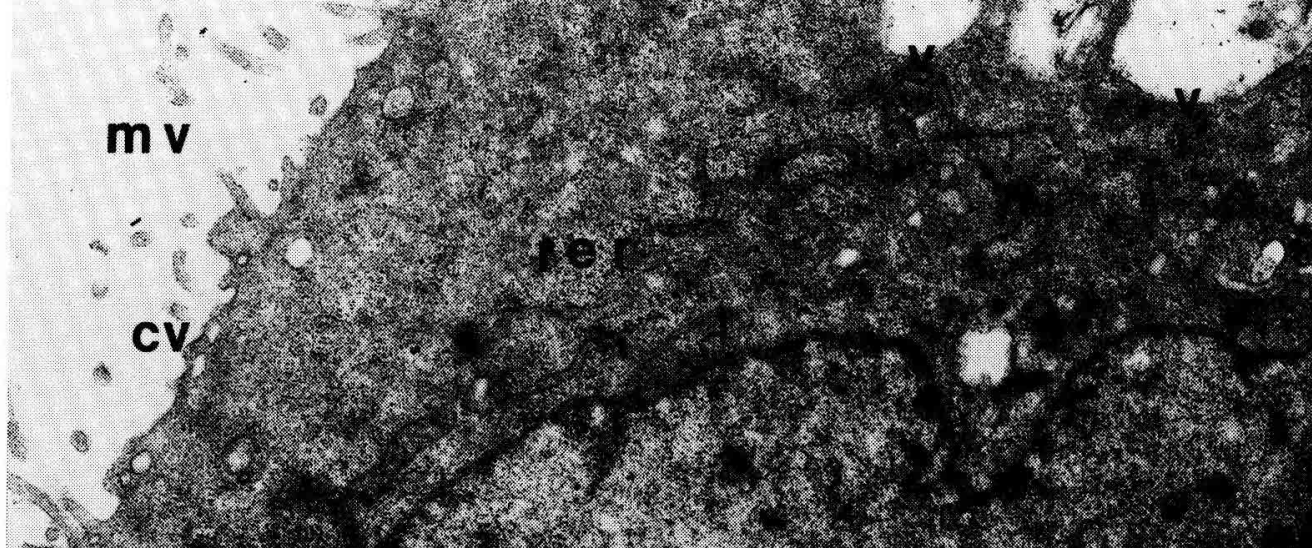

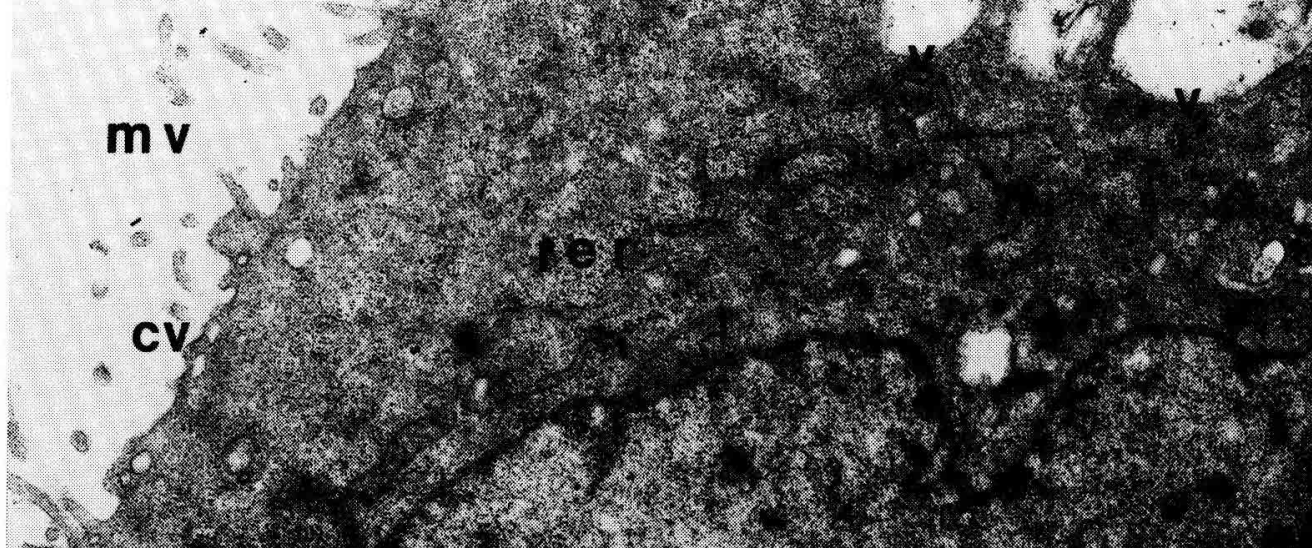

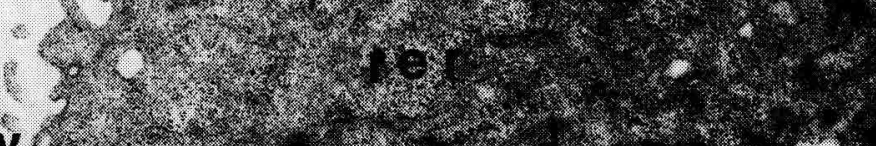

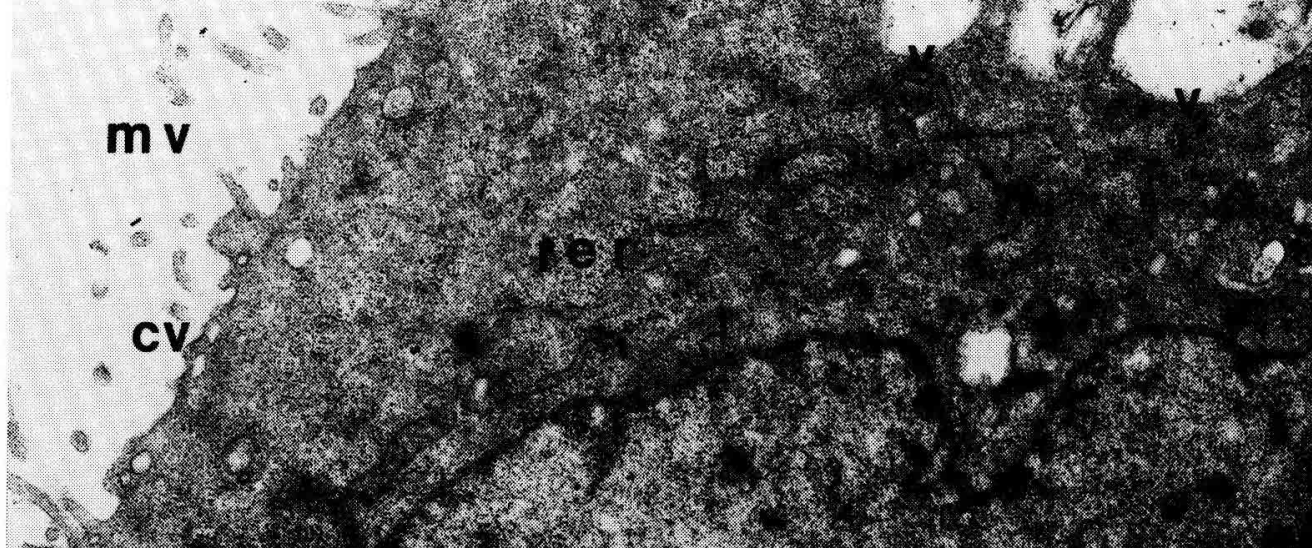

mas.

2.30?

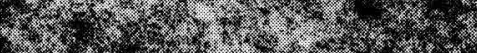

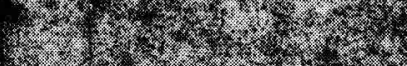

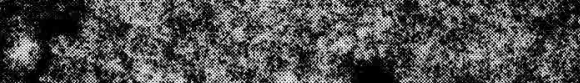

ats

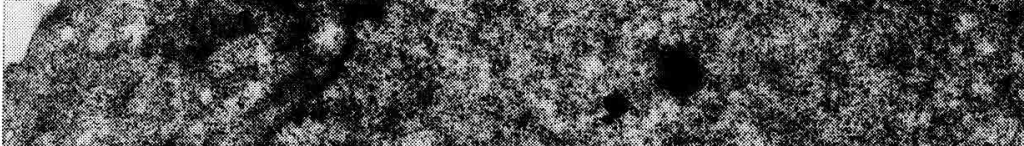

1
1

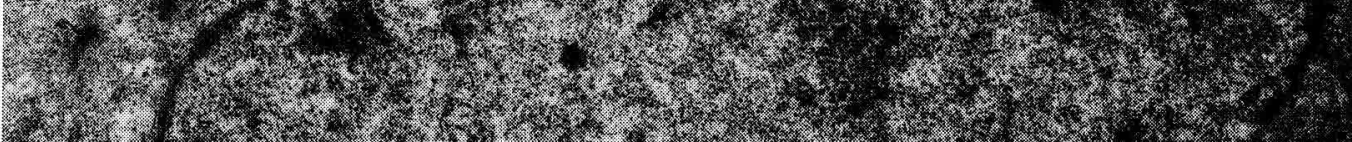

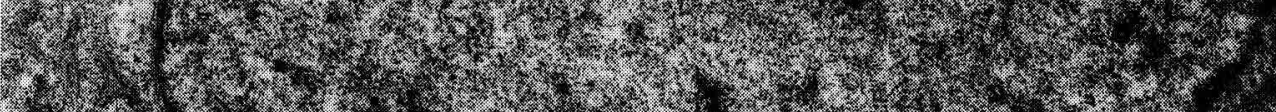

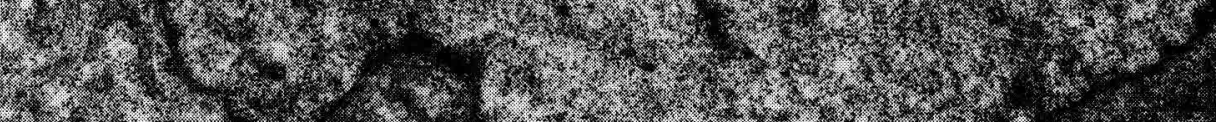
(2) 1.7.

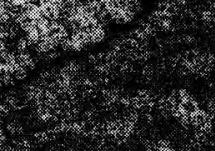

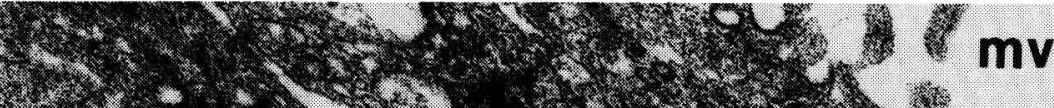

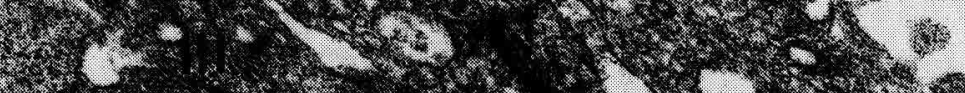

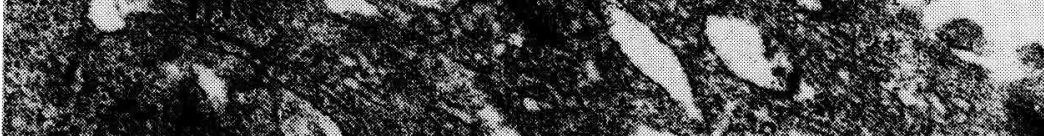

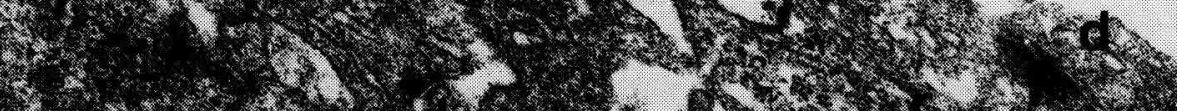

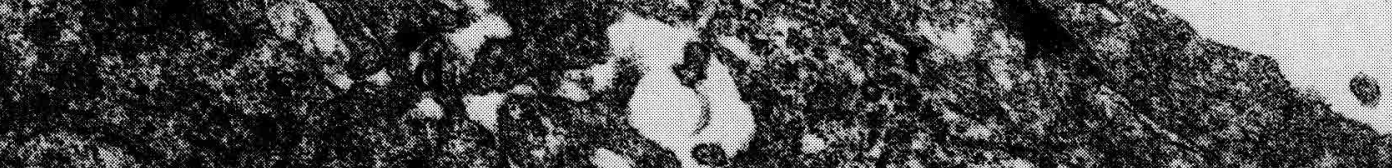

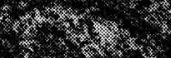

$$
\text { ?. }
$$
2. $1.1 \%$ - Star 15

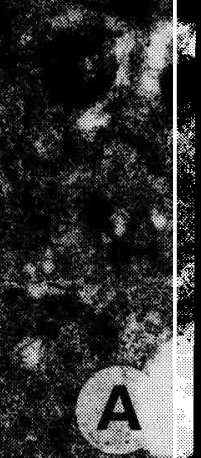


and the low staining with anti-vimentin antibody (less than 10\%) (Vettenranta et al, 1986; Mac Queen et al, 1987). Moreover, as early as the first $24 \mathrm{~h}$ of culture, 90$95 \%$ of cultured cells synthesized $\alpha$ hCG subunit, shown by staining with anti $\alpha$ hCG antibody (data not shown), and correlated by the level of secreted hCG and free hCG $\alpha$ subunit into the culture medium.

When the culture time increased, cells aggregated, and multinucleated cells appeared; the electron microscope, and a study of the secreted hPL level, provided evidence that these cells were able to differentiate into syncytiotrophoblasts in vitro, and to synthesize and secrete hPL, a placental hormone found only in the syncytial epithelial layer of villous tissue (Simpson and MacDonald, 1981; Hoshina et al, 1982; Hoshina et al, 1985). The time required in vitro, to observe the formation of aggregated cells and the formation of the syncytiotrophoblast was identical for either first trimester, or term placenta (Kliman et al, 1986). As a function of culture time, a parallel study was performed to determine the level of secreted intact hCG and its free $\alpha$ and $\beta$ subunits, using specific monoclonal antibodies and radiometric assay (Bellet et al, 1986; Ozturk et al, 1987). In contrast to data obtained from either term placenta cultured cells (Kliman et al, 1986), or from first trimester explant cultures (Maruo et al, 1987), which reported either an increase of hCG at $48 \mathrm{~h}$ of culture, or a decrease of hCG at each culture time, we observed a stable secretion of hCG during the first $3 \mathrm{~d}$ of cell culture. The discrepancy between these data could be due to the different assay used for the evaluation of secreted hCG, to the difference between early and term placenta, or to the difference in the procedure of cell isolation and culture.

Although we observed a decrease in the secretion of hCG and of its free $\alpha$ and $\beta$ subunits on the fourth day of culture, these secretions could be induced again by the addition of dibutyryl cAMP. This last result, and the increase of secreted hCG in the continuous presence of dibutyryl CAMP, as compared to the control, suggests that these cells possessed the potential for synthesizing hCG, but that specific inductors were missing in our culture conditions. These results are in agreement with the key role of cAMP in the regulation of hCG synthesis (Jameson et al, 1987; Zhou et al, 1987; Nulsen et al, 1988). Moreover, the addition of CAMP stimulated the secretion of hPL by cultured cells, in contrast to previous results obtained for term placenta (Zeitler et al, 1983). These results support a stimulatory role of the adenylate cyclase pathway as an intracellular regulator of human trophoblastic endocrine activities, not only for hCG, but also for hPL, in the first trimester placenta.

Fig 2. Electron micrograph of trophoblastic cells after $96 \mathrm{~h}$ in culture $(x 7400)$. A: Abundant microvilli (mv), coated vesicles (cv), rough endoplasmic reticulum (rer) and large electron dense vacuoles (v) ( $\times$ 8800). B: Clump of 4 adherent cells (I, II, III, IV) during cellular fusion showing desmosomes between adjacent cell membranes (d), intermediate filaments ( $f)$, lysosomes (ly) and osmophilic lipids (l). The cell surface exhibited microvilli (mv) on the outside of the clump and in the intercellular space between adjacent cells ( $\times$ 9400). 

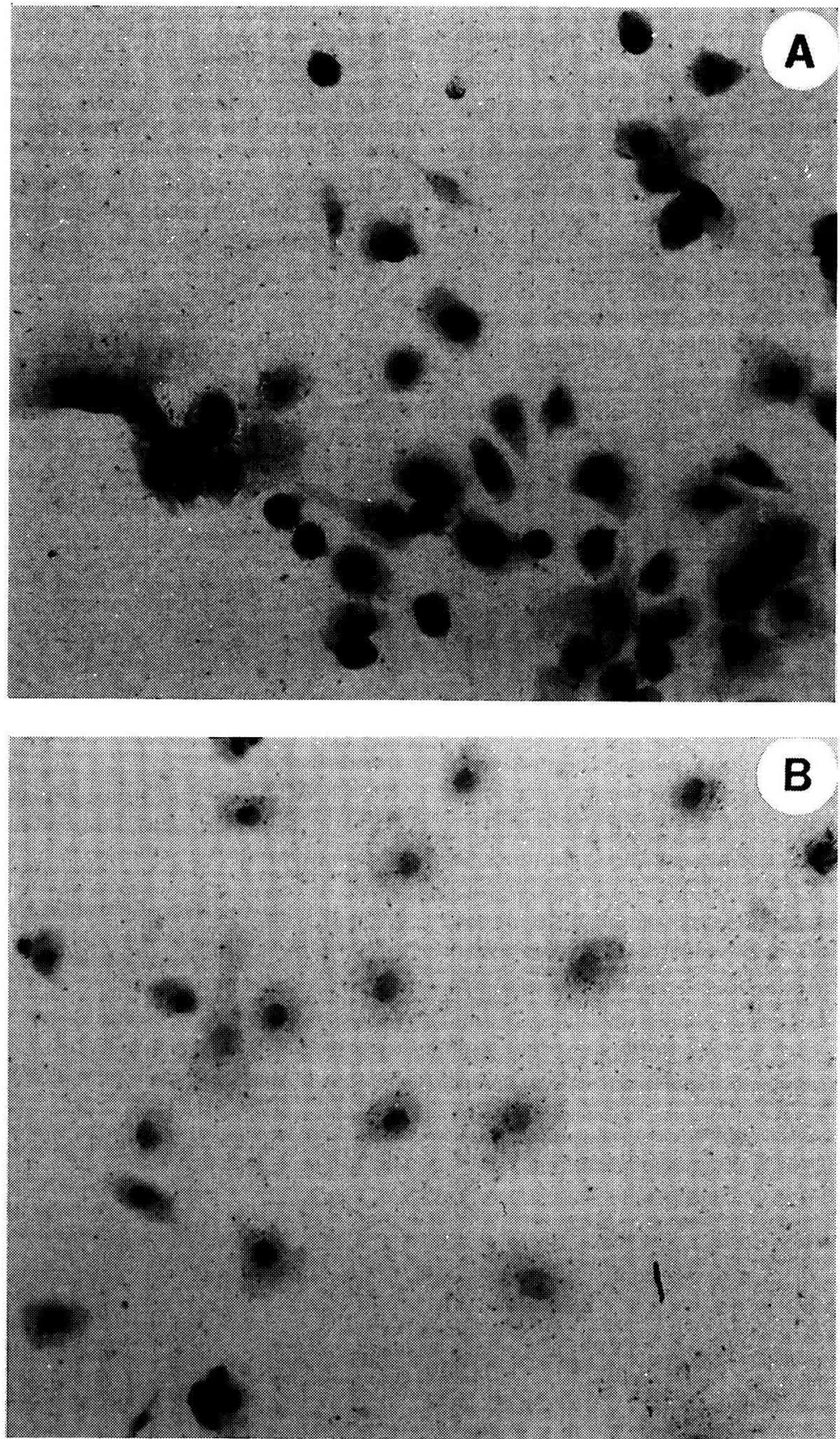

Fig 3. Immunohistochemical staining of cultured trophoblastic cells. At $24 \mathrm{~h}$ of culture, cells were stained for cytokeratin (A), and for vimentin (B). 

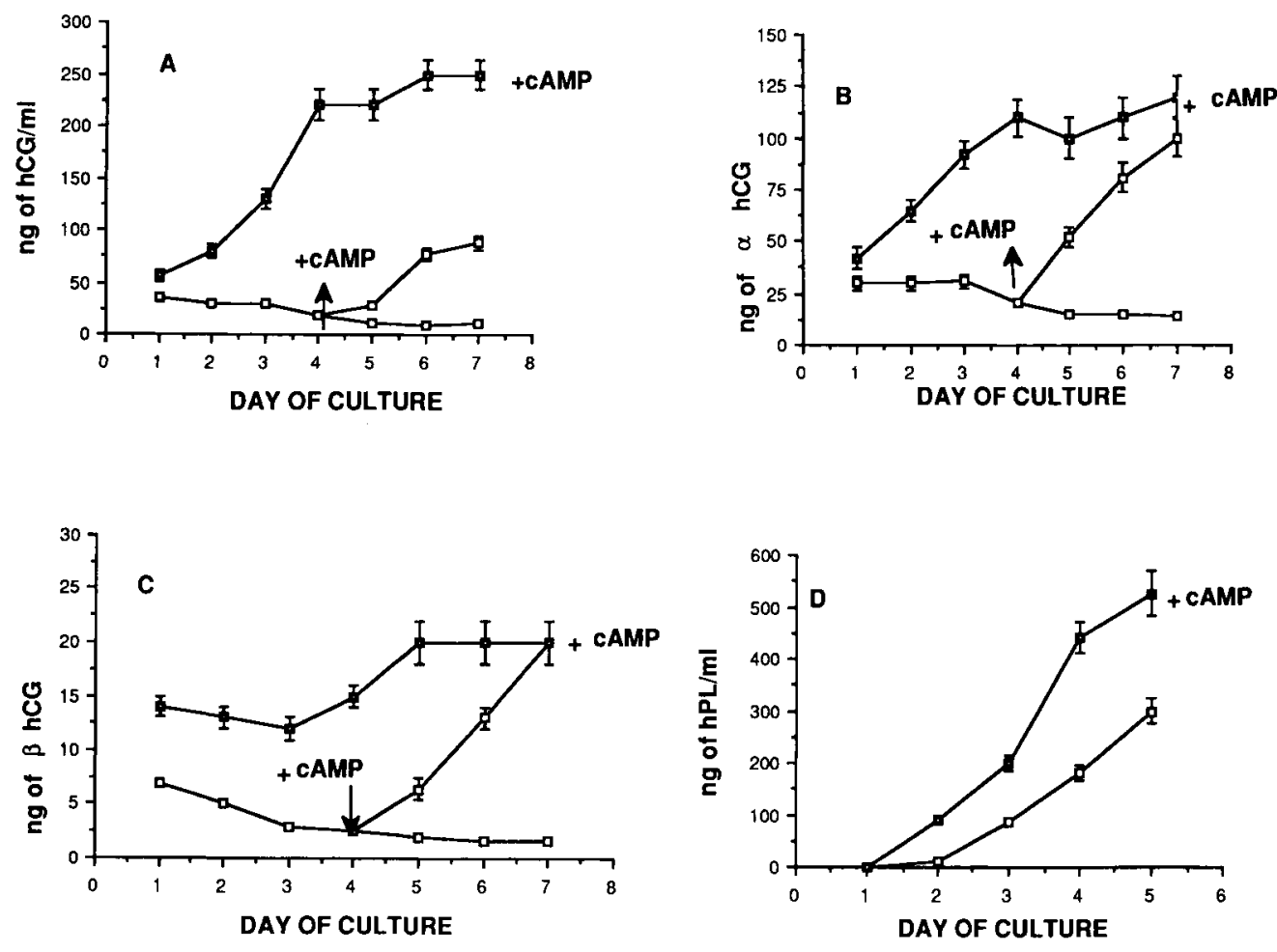

Fig 4. Hormonal secretion by trophoblastic cells in culture. Cells were cultured, as described in Materials and Methods, in the presence or in the absence of dibutyryl cAMP (mM). Dibutyryl cAMP was added either at $2 \mathrm{~h}$, or at $96 \mathrm{~h}$ of culture. The media were removed daily and replaced with fresh medium. The results are the mean \pm SD of duplicate incubation from 4 separated incubations. A: $\mathrm{ng}$ of intact hCG/ml/24 h; B: $\mathrm{ng}$ of free $\alpha \mathrm{hCG} / \mathrm{ml} / 24 \mathrm{~h} ; \mathrm{C}: \mathrm{ng}$ of free $\beta \mathrm{hCG} / \mathrm{ml} / 24 \mathrm{~h} ; \mathrm{D}: \mathrm{ng}$ of $\mathrm{hPL} / \mathrm{ml} / 24 \mathrm{~h}$.

\section{ACKNOWLEDGMENTS}

This work was supported by a grant from "La Fondation pour la Recherche Médicale" and "La Ligue Parisienne Contre le Cancer". We would like to thank D F Lewin and the staff of the department of gynecology (Hopital Saint Vincent de Paul, Paris) for their cooperation.

\section{REFERENCES}

Adamson ED (1987) Expression of protooncogenes in the placenta. Placenta 8, 449466

Bellet DH, Ozturk M, Bidart JM, Bohuon CJ, Wands JR (1986) Sensitive and specific assay for human Chorionic Gonadotropin 
based on anti-peptide and anti hCG monoclonal antibodies: construction and clinical implications. J Clin Endocrinol Metab 63, 1319-1327

Chaouat G (1987) Immunité et grossesse. Médecine et Sciences 3, 599-607

Glass RH, Aggeler J, Spindle A, Pedersen RA, Werb $Z$ (1983) Degradation of extracellular matrix by mouse trophoblast outgrowth: a model for implantation. J Cell Biol 96, 1108-1116

Hoshina M, Boothby M, Boime I (1982) Cytological localization of Chorionic Gonadotropin $\alpha$ and placental lactogen mRNAs during development of human placenta. J Cell Biol 93, 193-198

Hoshina M, Boothby M, Hussa R, Pattillo R, Camel M, Boime I (1985) Linkage of human Chorionic Gonadotropin subunit and placenta lactogen biosynthesis to trophoblast differentiation and tumorigenesis. Placenta 6, 163-176

Jameson LJ, Deutsch PL, Gallagher GD, Jaffe RC, Habener JF (1987) Trans-Acting factors interact with a cyclic AMP response element to modulate expression of the human gonadotropin a gene. Mol Cell Biol 9, 3032-3040

Kliman HJ, Nestler JE, Sermasi E, Sanger JM, Strauss III JF (1986) Purification, characterization, and in vitro differentiation of cytotrophoblasts from human term placentae. Endocrinology 118, 1567-1582

Lachlan HD, Lopata D (1988) Chorionic Gonadotropin secretion by human embryos in vitro. J Clin Endocrinol Metab 67, 13221324

Loke YW (1983) Human trophoblast in culture. In: Biology of trophoblast (Loke YW, Whyte A, eds) Elsevier, 663-686

Mac Queen SD, Krichevsky A, Boime | (1987) Isolation and characterization of human cytotrophoblast cells. In: Trophoblast Research (Miller RK, Thiede HA, eds) Plenum Medical Book Company, New York, London, 423-445

Maruo $T$, Matsuo $H$, Oishi $T$, Hayashi $M$, Nishino R, Mochizuki M (1987) Induction of differentiated trophoblast function by epider- mal growth factor: relation to immunohistochemically detected cellular epidermal growth factor receptor levels. J Clin Endocrinol Metab 64, 744-750

Nulsen JC, Woolkalis MJ, Kopf GS, Strauss III JF (1988) Adenylate cyclase in human cytotrophoblast: characterization and its role in modulating human Chorionic Gonadotropin. $J$ Clin Endocrinol Met 66, 258-265

Ozturk M, Bellet D, Manil L, Hennen G, Frydman R, Wands JR (1987) Physiological studies of human Chorionic Gonadotropin (hCG), $\alpha$ hCG, $\beta$ hCG as measured by specific monoclonal immunoradiometric assays. Endocrinology 120, 549-558

Patillo RA, Hussa RO, Yorde DE, Cole LA (1983) Hormone synthesis by normal and neoplastic human trophoblast. In: Biology of Trophoblast (Loke YN, Whyte A, eds) Elsevier, 293-310

Rydnert J, Pfeiffer-Ohlsson S, Goustin S, Ohlsson R (1987) Temporal and spatial pattern of cellular myc oncogene expression during human placental development. Placenta 8, 339-345

Simpson ER, MacDonald PC (1981) Endocrine physiology of placenta. Ann Rev Physiol 41, 163-173

Vettenranta $K$, Von Koskull $H$, Heikinheimo $M$, Raivo KO (1986) Cytoskeletal markers and specific protein production in cells cultured from human first trimester placentae. In vitro Cell Develop Biol 22, 100-106

Wild AE (1983) Trophoblast cell surface receptors. In: Biology of Trophoblast (Loke YW, Whyte A, eds) Elsevier, 473-480

Zeitler P, Markoff E, Handwerger S (1983) Characterization of the synthesis and release of human Placental Lactogen and human Chorionic Gonadotropin by enriched population of dispersed placental cells. J Clin Endocrinol Metab 57, 812-818

Zhou F, Yuen BH, Leung PCK (1987) Effects of adenosin 3' 5'-cyclic monophosphate, forskolin, and cholera toxin on hormone production in human term placental cells. Am J Obstet Gynecol 156, 420-424 